\title{
Conceptualising and designing a collaborative blended e-learning environment for schools: drawing from evidence-based practices
}

\begin{abstract}
An exploration into two different approaches used by teachers to personalise teaching and learning within their classroom and schools is presented in this paper. The first approach involves a process of collaborative work-based action research and the second involves collaborative use of a computer-aided on-line assessment for learning tool. Both approaches are exemplified by purposive selection of case studies where teachers utilise assessment for learning in order to personalise teaching and learning and raise outcomes for pupils. In this paper we draw upon findings from this exploration to inform and validate the conceptualisation and design of an integrative model for a collaborative blended e-learning environment within which teachers and pupils are engaging in reciprocal learning. (Abstract)
\end{abstract}

\section{Keywords - blended e-learning, action research, assessment for learning, collaborative inquiry communities}

\section{INTRODUCTION}

Whilst there are many descriptions and even several approaches for personalisation of teaching and learning, Hart's description of 'true participation' in which participation is classified as 'adult-initiated shared decisions with children' [1:8] is relevant to the approach advocated in this paper. In that, within the educational context, pupils are invited to participate and co-lead with their teachers in the decision making about personalising their learning experiences and also about what, where and how they want to learn.

In this paper we conceptualise a collaborative blended e-learning environment (CBeL) for personalisation of teaching and learning for both teachers and pupils 'that recognises diversity, difference and individuality in the ways learning is developed, delivered and supported. ... and recognizes social, cognitive and physical differences and diversity' [2: 184]. In presenting $\mathrm{CBeL}$ as a model the following three premises for personalisation of learning are considered for both teachers-as-learners and pupils-as learners:

- The learning curricula is appropriate for the ability of the learner

- The assessment is appropriate for learning

- The learner has an element of choice and control over their learning.

Inherent within the model design is setting the context for teacher and pupil constructivism which lends to a 'intergenerational dialogue' and engagement between teacher and pupil [3].

\section{METHODOLOGY}

This is an exploratory study [4] of two different approaches used by teachers to personalise teaching and learning within their classroom and schools. Both approaches are exemplified by purposive selection of case studies which utilise assessment for learning (AfL) in order to personalise teaching and learning and raise outcomes for pupils. The first approach involves a process of collaborative work-based learning and the second involves use of a computer-aided on-line assessment for learning tool. The study draws upon the application of situated learning theory and increasing peripheral participation within communities of practice [5], [6]. This is within an educational context focusing upon student-centred learning. It draws upon multiple sources of evidence and interpretive analysis guided exploration of this evidence [7]. Participants' rights to anonymity and confidentiality was respected and identities protected [8].

$\overline{\text { InfoMentor Ltd }}$

Corresponding Author:

Sveta Mayer ${ }^{1}$ Institute of Education, University of London.

Email: s.mayer@ioe.ac.uk 
Mayer, S, Cotgreave, G., Rosenkvist, M., Einarsdottir, V. and Osborne, P. (2011)

Proceedings of Annual International Conference on Education and E-Learning 2011 p136-145.

Global Science and Technology Forum: http://dl.globalstf.org/

\section{METHODS}

\section{A. Case Study 1 - Practitioner Action Research on Assessment for Learning}

Case study one presents collaborative work-based learning undertaken by teachers in UK schools who took part in the UK Teacher Development Agency for Schools Professional Development Programme ${ }^{1}$. Teachers engaged in a process of collaborative work-based action research following a collaborative inquiry approach [9] that drew upon the central premise of action research methodology. This approach follows the guiding principles of Kurt Lewin [10] applied these to the education context as determined by Kemmis and McTaggart [11] and Bray et al [12]. Teachers thereby engaged in reflexive learning cycles of Planning, Acting, Observing and Reflecting together as inquiry-based professional learning communities [13]. Each teacher led and conducted their own action research project and established their own collaborative inquiry communities (collaborative research groups) by inviting participation from school staff and pupils. These collaborative inquiry communities were established following the principles of legitimate peripheral participation which govern situated learning [5].

Two vignettes are presented in this case study from individual teachers who were interested in establishing collaborative inquiry communities with school staff and pupils and focusing their action research upon applying and evaluating strategies for AfL relevant to their pupils' context. They thereby drew upon principles for formative assessment for learning in the classroom, as advocated by Black et. al. [14] to personalise teaching and learning. Methods for data collection, generation of audit trail, data analysis, research-based reification and final research report write-up evidenced teachers' research. Evaluations completed by teachers also informed this case study. Teachers received academic support on conducting their action research, establishing their inquiry communities and analysing the impact of their interventions through individual face-to-face and group participation. Their research reports were accredited at M-level.

\section{B. Case Study 2 - Pupils' Computer-aided Assessment for Learning}

The second case study presents a vignette on utilisation of a computer-aided on-line assessment system by schools in Sweden to support personalised teaching and learning through teacher and pupil engagement with formative assessment. The on-line tool is implemented into schools by Mentor ehf, an Icelandic company which provide web based assessment solutions for schools in Iceland and Sweden. Since 2005 a new three step process for learning has been introduced for all primary and secondary schools in Sweden (see Fig 1). The process is cyclical and called "An Individual development plan with written assessments" (Individuell utvecklingsplan - IUP - med skriftliga omdömen). This is stipulated in the "Compulsory School Ordinance for primary and secondary schools" (Grundskoleförordningen).

This InfoMentor on-line assessment system (InfoMentor System) engages subject teachers, form teachers, pupils, and parents in this three step cyclical learning process and enables collaborative appraisal of pupils' progress in school during the school year. Pupil's and parent's involvement is not compulsory but voluntary as pupils and parents are invited to participate. Also pupils' own reflections are at play in step 2 and 3 . In addition, the InfoMentor System also supports the subject teacher by ensuring personalised learning and professional development through self-evaluation. The InfoMentor self-evaluation tools for teachers are introduced in training. Teachers continue to use these tools in practice to audit differentiation of curriculum delivery that meets the needs of the individual pupils in their class.

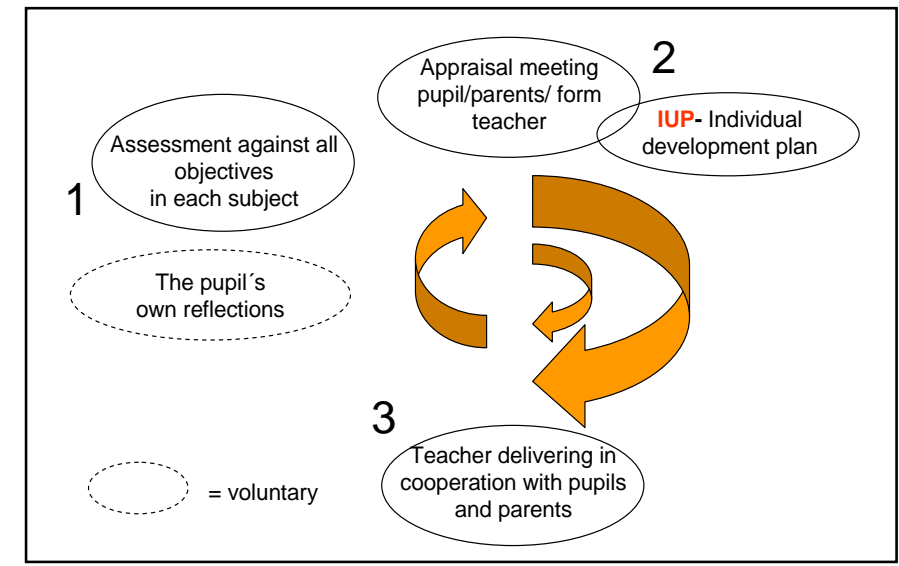

Fig 1. The InfoMentor three step process for learning called "An Individual Development Plan with written assessments" (Individuell utvecklingsplan - IUP - med skriftliga omdömen)

${ }^{1}$ http://www.tda.gov.uk/partners/cpd/ppd.aspx

Corresponding Author:

Sveta Mayer ${ }^{1}$ Institute of Education, University of London.

Email: s.mayer@ioe.ac.uk 
The cyclical learning process with each cycle begins with a subject teachers' summative assessment of pupils' using assessment symbols to indicate levels of achievement, the subject teacher also writes formative assessment comments into the InfoMentor System (Step 1 in Fig 1 and see Fig. 2). This is on an ongoing basis throughout the school year. Parents have access to this screen via the web. This screen is read only for the pupil and parents. The summative markings in the different columns are saved in a database that generates the data as pie charts and lego symbols where each goal achieved represents one spike or point on the Lego block (not shown). On a mid-termly basis form teacher invites pupils and their parents for a consultation meeting during which they discuss the pupils' achievements by considering the subject teachers inputted summative and formative assessment data and negotiate learning needs and goals to be achieved (Step 2). The form teacher then writes this formative assessment into the InfoMentor System (screen not shown) which generates the Individual Development Plan. This is also accessed via the web and is read only for pupil and the parents. Individual Development Plans are generated once a term between mid to end term. The subject teacher uses this information to inform and personalise their teaching, thereby targeting pupil learning (Step 3) whist also actioning on Step 1.

This approach is based upon the principles of formative and summative evaluation [15]. Data collection methods included tracking pupils' development and progress from information logged onto IUPs, pupil achievement and evaluation with testimonials from teachers and pupils. These methods evidenced the findings and will be presented in the paper.

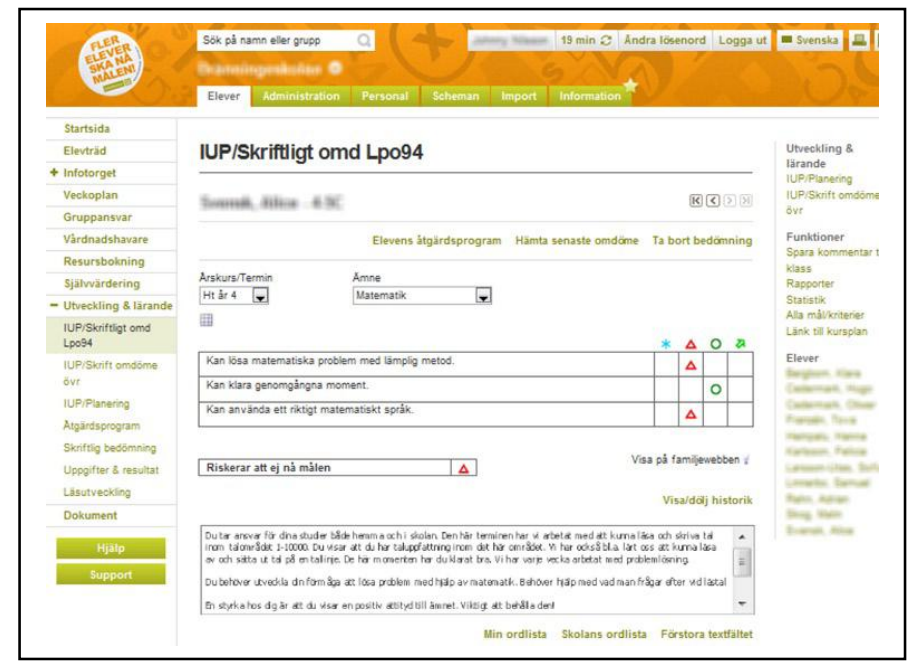

Fig 2. Screenshot from the InfoMentor system showing the screen where the subject teacher inputs the summative assessment and writes formative assessment. The assessment symbols from left to right columns are: blue star $(*)=$ This has not been covered/taught this term; red triangle $(\Delta)=$ Does not have the expected knowledge for this school year; green ring $(O)=$ Has the expected knowledge for this school year; and green arrow $(\gtrsim)=$ Has well above the expected knowledge for this school year.

\section{VIGNETTES AND FINDINGS}

\section{A. Case Study 1 - Practitioner Action Research on Assessment for Learning}

1) Vignette 1: A secondary school in the London Borough of Brent sought to implement whole school Assessment for Learning. In order to achieve this, an assistant principal formed and led an inquiry-based professional learning community with departmental representatives from across the school. Each departmental teacher focused upon establishing their own collaborative inquiry communities and conducting action research on applying different AfL strategies in the classroom. Strategies included use of guidelines for questioning, dialogue using the 'no hands up rule' and self evaluation using thinking skills.

In the vignette presented here, an action research project conducted by EW, a science teacher and KS3 (year 7-9) co-ordinator, with her science colleagues and pupils focused upon collaboratively establishing guidelines for success criteria using questioning and peer group work to support pupils with learning of science curriculum - investigative skills in science lessons. The guidelines for success criteria were presented as a checklist for pupils to complete while conducting a science investigation in class in small groups. EW began by designing a success criteria template. In her research report she explains:

'I designed a template for the success criteria ... to assist students write up a scientific investigation. The template includes the success criteria for the aim, prediction, variables, method, results, graph, conclusion 
and evaluation. The success criteria were given in form of questions, to lead students to do their own independent writing up of an experiment'.

The premise was for pupils to use the template in the lesson and to give pupils the opportunity to do self assessment as well as peer assessment before doing their own independent writing up of the experiment. She trialled her template in her own year 7 science class first and reflected pupils in her mixed ability class were using the template in different ways. Higher ability pupils appear to use the template to support self-reflection upon prior learning whilst lower ability pupils used it as a learning tool to acquire new learning. She reflected:

'more able students use it as guidelines to do the writing up in their own words, but the less able use it more directly by answering the questions. In both these scenarios the success criteria has been used to the best way suitable for the students' needs.'

EW realised in order to engage her lower ability pupils in self-reflection and not just in answering questions she needed to give an opportunity for her pupils to make suggestions to amend the template to make it easier for them to do this in the future. She prompted feedback from her pupils and taking heed of comments from her lower ability pupils: 'I think that the language is too hard.' and 'Make it more short and interesting.' as well as reflecting upon the learning experience she was initiating, she redesigned the template into specific statements with visual prompts for engagement. These prompts were to indicate whether they had worked independently or in a group (Sun for independent work and Cherries for group work). Fig 3. shows the success criteria statements for producing graphs along with the visual prompts.

EW also realised she needed a more robust way of gauging the success of the new template because she recognised the need for developing differentiated templates to support learning for her higher ability and lower ability pupils. To do this she continued to seek informal feedback from her pupils and now included visual prompts for affect (happy or sad face, not shown) for pupils to indicate how well they feel they are doing in their learning and also in using the success criteria template. Her analysis of these responses indicated that pupils were using the templates to support their own learning and were also increasingly using it to support peers' learning. EW also found pupils needed time to understand and use the AfL strategy. Commenting on her analysis of implementing success criteria template in her class to support learning EW reflected:

'If students know what to do, practice procedures, understand the terminology they complete a task more successfully and enjoy the journey of learning. ... they appreciate a familiar structure to work in..'

\begin{tabular}{|c|c|c|}
\hline \multicolumn{3}{|l|}{ KS3 Science Curriculum: Graphs } \\
\hline Success Criteria statements for Science: & $\hat{\theta}$ & S \\
\hline Label the axis ( $\mathrm{x}$-axis - independent variable, $\mathrm{y}$-axis - depen & & \\
\hline \multicolumn{3}{|l|}{ Put units } \\
\hline \multicolumn{3}{|l|}{ Use the correct scale on both axis } \\
\hline \multicolumn{3}{|l|}{ Plot points correctly. } \\
\hline In case of a line graph, draw a line of best fit & & \\
\hline
\end{tabular}

Fig 3. An exemplar from EW's success criteria template showing success criteria and visual prompts for independent learning ( learning ( $\left(\frac{2}{2}\right)$. The complete template includes the success criteria for the aim, prediction, variables, method, results, graph, conclusion and evaluation.

In addition, to determine if pupils attributed their progression in science to the AfL strategy used in the lesson she asked pupils to specifically name the success criteria they would use to draw a graph. 56\% pupils in KS3 classes indicated they were able to. However this also means $44 \%$ pupils were unable to. EW reflected these are results from mixed ability classes and considerations for differentiating to meet the needs of the learner were still relevant.

In this way EW established a reciprocal system of feedback between herself and her pupils; gauging an understanding of how well they were doing in lesson and in using the AfL strategy to support their own learning. Following the success in implementing the AfL strategy to support delivery of science curriculum with her Year 7 class, EW led a professional development training session on AfL in her school. Following this she extended her collaborative inquiry community and involved all KS3 science teachers in implementing the AfL strategy to all Year 7, 8 and 9 classes. EW was particularly interested in whether, following the training, the AfL strategy was being used by teachers in their classes. She canvassed this and found $70 \% \mathrm{KS} 3$ teachers regularly used the AfL strategy. Of the $30 \%$ who did not she elicited they either 'do not have time or opportunity' or 'do not know where to start as there is individual/personal criteria for success in any given learning moment'. Teacher testimonials on whether using the AfL strategy changed their teaching or their pupils learning experience, indicate teachers' perceptions of the relevance of the AfL strategy to teaching and learning (Table 1). 
Mayer, S, Cotgreave, G., Rosenkvist, M., Einarsdottir, V. and Osborne, P. (2011)

Proceedings of Annual International Conference on Education and E-Learning 2011 p136-145.

Global Science and Technology Forum: http://dl.globalstf.org/

The above vignette of EW's action research indicates therefore key challenges to personalising learning were pupils' cognitive engagement whilst using the AfL strategy, pupils' engagement being dependent upon differentiation and whether teacher's give pupils the opportunity for engagement in the AfL strategy.

TABLE I TEACHER TESTIMONIALS

\begin{tabular}{|c|c|}
\hline \multicolumn{2}{|c|}{ How has the use of success criteria changed } \\
\hline Your teaching & Your pupils' learning \\
\hline (setting) clearer more specific tasks & Help students self and peer evaluate \\
\hline $\begin{array}{l}\text { Help me to motivate students so they know what to do and gives } \\
\text { them idea of how to finish the task }\end{array}$ & $\begin{array}{l}\text { The outcome is much better, pupils, time their work better, because } \\
\text { they see how much more is expected from them }\end{array}$ \\
\hline I am more aware of who has learned and what they have learned & $\begin{array}{l}\text { Sometimes get the students to work own success criteria out, they } \\
\text { like it }\end{array}$ \\
\hline Brings focus & Students are focused on outcomes and get better results \\
\hline It caters for all students with everyone achieving something & It helps motivation as all students achieve something \\
\hline Better planning and suitable activities to meet criteria & Improved level of assessment \\
\hline I am clearer about what is expected & Pupils understand what they need to do to achieve \\
\hline $\begin{array}{l}\text { Become more structured and focused, target-driven, helped with } \\
\text { modeling }\end{array}$ & Clarifies their understanding of a task \\
\hline Developing specific skills activities & Inspired specific skills \\
\hline $\begin{array}{l}\text { I look for opportunities to use success criteria as appropriate in } \\
\text { lessons }\end{array}$ & $\begin{array}{l}\text { Students seem to grasp difficult tasks a little easier (not all students, } \\
\text { all the time) }\end{array}$ \\
\hline
\end{tabular}

2) Vignette 2: Indications that engagement with AfL strategies can be increased if teachers and pupils use Web technologies was gleaned from another action research project conducted by RD. RD's position within a large urban mixed 11-19 comprehensive school within Greater London is that of Director of ICT with over arching responsibility for ICT. RD was a member of an across school inquiry-based professional learning community with school representatives from across the schools involved. Teachers established their own collaborative inquiry communities and conducted their own action research. In his action research RD utilised Web 2.0 technologies and the AfL strategies of peer assessment and formative teacher feedback. In this way he engaged year 10 pupils in blended e-learning in order to support the delivery of ICT curriculum and raise outcomes for pupils. In the vignette presented here, RD initially engaged with his year 10 class pupils in using graphics software to create 3D images as part of their ICT coursework. The theme for creating these images was healthy eating so pupils were involved in designing and creating fruit and vegetable cartoon characters using graphics software.

RD engaged pupils to independently research the healthy eating theme and then engaged them in writing a wiki about their learning so that they pooled their understanding on this theme. He then engaged pupils in creating the 3D images and utilized blogging to engage pupils in peer assessment of the images they'd created. As part of this research he analysed the 'types' of comments pupils and teachers were making to establish an assessment framework (akin to EW's success criteria). RD found this to be an iterative process of refinement. In his first trials he recognised that pupils' comments lacked constructive feedback. In his report he coveys how he considered addressing this and commented:

'Based on these findings I would suggest that a teacher driven activity with examples of different work, perhaps projected on the board are self-assessed first by each student, with the students given the assessment framework criteria as a paper based exercise first with a $Q \& A$ and class discussion based on their personal assessments of each and with an emphasis on the reasoning behind their conclusions. This kind of assessment framework technique needs to be formally taught in its own right on deeper more substantial level before being applied within the blog. This whole activity of learning to assess within the framework needs to be assessed itself (!), ideally within the lesson to ensure that the students are clear before they embark on the blog, and that the teacher is clear about their students understanding'.

RD also extended his collaborative inquiry community to engage all year 10 pupils and teachers in the department. In addition teachers were now also encouraged to provide formative feedback to pupils using blogging. In a survey of teachers in his department RD determined whether formative feedback given to pupils by their ICT teachers on their blogs were used by pupils in their learning. In his analysis (Table 2) he found this to be variable within the department:

\section{TABLE II DEPARTMENT SURVEY}

\begin{tabular}{|l|c|c|c|c|}
\hline \multicolumn{5}{|c|}{ \% Students using their teachers' formative feedback received through blogging } \\
\hline & Teacher A & Teacher B & Teacher C & Teacher D \\
\hline In their classwork & 98 & 18 & 80 & 67 \\
\hline To inform and improve work & 98 & 10 & 69 & 60 \\
\hline
\end{tabular}

Corresponding Author:

Sveta Mayer ${ }^{1}$ Institute of Education, University of London.

Email: s.mayer@ioe.ac.uk 
While RD's research indicated how blended e-learning could be effectively implemented within the classroom to increase pupils and teachers engagement in the learning process his research also indicated that to ensure personalised learning so that pupils' were cognitively engaged, training for both pupils and teachers was needed. For pupils training in peer assessment for learning was important and for teachers training on use of Web 2.0 technologies to deliver curriculum was important. RD clearly recognised the potential for this blended learning approach to AfL in supporting teaching and learning in all subjects but also that there were issues regarding 'cybersafety'. He commented in his report:

'These assessment framework ... could also be adopted as a generic approach (for formative feedback). ... (A)fter the initial assessment framework and blogging skills are taught in class. In fact if these were taught in one class, say ICT, ... application throughout other subjects would be made easier as students throughout the school, regardless of what subject they were in they would have a generic set of skills for using an assessment framework with a blog. Students would also be taught blog etiquette and sign the blog and wiki agreement (warranty), this would happen at the start of Year 7.'

3) Findings: The collaborative work-based action research projects undertaken by teachers indicated:

- Teachers worked effectively at personalising teaching and learning when they collaborated with each other, critically reviewed their practices and invited pupil participation. Participation, be that at level of teacherto-teachers, teacher-to-pupils, pupils-to-teacher or pupil-to-pupils, is an important aspect of collaborative learning.

- Pupils need to be cognitively aware of the AfL strategies they are using and how these develop their learning. The use of symbols and prompts aid this.

- Web 2.0 technologies can be successfully used to engage teachers and pupils in collaborative learning.

- Training for both pupils and teachers to utilise AfL strategies as a tool, either face-to-face or via use of Web 2.0 technologies is needed.

\section{B. Case Study 2 - Pupils' Computer-aided Assessment for Learning}

1) Vignette 3: The case study school is situated in a small town that is part of the municipality of Habo. The school district is run by the local authority and consists of five playschools and one school to year 5 of the compulsory 9 year primary school in Sweden. The pupil is a girl, AS, that was in year 4 at the time taught in an age-mixed class year $4-5$. In this vignette AS's progress in Maths will be considered and tracked between two terms; Autumn and Spring. By mid-term in each term, AS, her parent and her form teacher held consultations to review her progress and set targets and goals to be achieved. This review is conducted using the InfoMentor System as described in Methods above.

For AS' Autumn term consultation, InfoMentor System had logged AS' Maths teachers' summative diagnostic test score for AS in the subject as 5/19. Her subject teacher deemed she was at risk of not achieving her targets and was given a red triangle $(\Delta)=$ Does not have the expected knowledge for this school year in Maths. Her teachers' formative assessment indicated AS needed to improve in Maths and in the Spring term needed to train further on reading the clock; analogue and digital time (Step 1, Fig 2). By the Spring term the InfoMentor system indicated AS's summative diagnostic test score in the subject hadn't changed and her subject teacher still deemed she was at risk of not achieving her targets.

However reviewing the progress AS made in Maths based upon the comments and reflections in her IUP, generated from her formative assessment (Step 2), it was evident that AS had made both academic and personal progress (Tables 3 and 4). This type of appraisal was possible because the InfoMentor System prompted reflections on achievement and aspirations as well as areas for improvement by using question prompts and the assessment symbols. There were specific prompts for consideration of academic progress (Table 3) and personal progress (Table 4). In this way it was evident that although AS hadn't made progress academically she had personally. Tracking her progress from Autumn to Spring term revealed AS remained motivated, continued to interact positively with her peers, was developing independent learning skills and a sense of autonomy.

The InfoMentor System is utilized within schools from year 1 to year 9 which means pupils, their parents and form teachers experience several cycles of reflection upon learning. Table 5 gives an indication of how year 9 pupils and teachers have experienced the InfoMentor System after one year.

2) Findings: Utilization of the InfoMentor System by participating schools indicated:

- Pupil, parent and teacher engagement in summative and formative evaluation along with pupils' self reflection was aided by the process of engaging with the InfoMentor on-line assessment tool.

- Pupils' self-reflections, learning objectives, goals and indication of intervention and support needs once entered into the on-line tool, generated an on-line Individual Development Plan. 
Mayer, S, Cotgreave, G., Rosenkvist, M., Einarsdottir, V. and Osborne, P. (2011)

Proceedings of Annual International Conference on Education and E-Learning 2011 p136-145.

Global Science and Technology Forum: http://dl.globalstf.org/

- An audit of pupils' academic and personal progress could be tracked over time and viewed by all teachers within the school.

- Teacher and pupil were able to review pupils' progress over all subjects and monitor achievement by indicators (scoring with symbols) of how far they had met learning objectives and goals they had set.

- The versatility of this on-line formative assessment tool is that the teacher may also gain an overview of the whole class progress thereby personalising teaching for the individual pupil as well as for the whole class.

- It was evident by engaging in the process of on-line formative assessment that pupil, teacher and parents were engaging in reflective learning cycles over time.

TABLE III PUPILS’ ACADEMIC PROGRESS

\begin{tabular}{|c|c|c|}
\hline \multirow[t]{2}{*}{$\begin{array}{l}\text { InfoMentor Formative Assessment } \\
\text { for pupil's academic progress }\end{array}$} & \multicolumn{2}{|c|}{$\begin{array}{c}\text { Individual Development Plan (IDP)/Planning Pupil's IDP/Planning Bränningeskolan: } \\
\text { Swedish Girl, AS, 4-5C Bränningeskolan }\end{array}$} \\
\hline & Autumn Term, 4th grade Formative Assessment & Spring Term, 4th grade Formative Assessment \\
\hline Evaluation of previous IDP/planning: & $\begin{array}{l}\text { AS had set the goal of learning all the strokes of the } \\
\text { analogue clock. She has succeeded with this and } \\
\text { can now continue with digital time. }\end{array}$ & $\begin{array}{l}\text { Your previous goal was to learn digital time. You still find this } \\
\text { difficult at times. }\end{array}$ \\
\hline $\begin{array}{l}\text { My goals for the following } \\
\text { subjects/activities are: }\end{array}$ & Learn digital time & $\begin{array}{l}\text { Learn multiplication tables } 2-5 \text { and } 10 \text {, and analogue and digital } \\
\text { time. }\end{array}$ \\
\hline Our tasks: Myself/my custodian: & Practise the clock at home and in school. & $\begin{array}{l}\text { Practise at these are two free websites where you can practise } \\
\text { math and multiplication with playing cards, maths games and } \\
\text { worksheets. }\end{array}$ \\
\hline The school's tasks: & $\begin{array}{l}\text { AS is sometimes given extra work like practising } \\
\text { the digital clock, for example. }\end{array}$ & Give AS extra practise on the digital clock in a small group \\
\hline Next evaluation and follow up: & Spring Term 2011 & Autumn Term 2011 \\
\hline
\end{tabular}

TABLE IV PUPILS’ PERSONAL DEVELOPMENT

\begin{tabular}{|c|c|c|}
\hline \multirow{2}{*}{$\begin{array}{c}\text { InfoMentor Formative } \\
\text { Assessment for pupil's personal } \\
\text { progress } \\
\text { What I am good at, } \\
\text { what I need to improve: }\end{array}$} & \multicolumn{2}{|c|}{$\begin{array}{c}\text { Individual Development Plan (IDP)/Planning Pupil's IDP/Planning Bränningeskolan: Swedish Girl, AS, 4-5C } \\
\text { Bränningeskolan }\end{array}$} \\
\hline & \multicolumn{2}{|c|}{\begin{tabular}{|l|l} 
Autumn Term, 4th grade Formative Assessment & Spring Term, 4th grade Formative Assessment
\end{tabular}} \\
\hline & AS works purposefully and always tries to do her utmost. & You always work well and try your utmost. \\
\hline & She is cooperative and active during lessons. & You are a good friend and can cooperate with others. \\
\hline & $\begin{array}{l}\text { She always says when something is on her mind, which is very } \\
\text { good. }\end{array}$ & $\begin{array}{c}\text { You are verbally active and say if something is } \\
\text { bothering you. }\end{array}$ \\
\hline & $\begin{array}{l}\text { She takes responsibility for her work, both at home and at } \\
\text { school. Appears uncertain at times, which is probably due to the } \\
\text { relatively large step up from 3rd to 4th grade. }\end{array}$ & $\begin{array}{l}\text { You have become better at working on your own. You } \\
\text { sometimes need help with instructions. }\end{array}$ \\
\hline & $\begin{array}{c}\text { AS says she is good at Nature Studies, Athletics, Music and } \\
\text { Photography, caring for animals and comforting friends, but } \\
\text { needs to concentrate on doing her homework, Swedish and } \\
\text { reading. }\end{array}$ & $\begin{array}{l}\text { You are good at practical subjects and have a good } \\
\text { imagination. }\end{array}$ \\
\hline
\end{tabular}

TABLE V PUPIL AND TEACHER TESTIMONIALS

\begin{tabular}{|c|c|}
\hline \multicolumn{2}{|c|}{ Reflections on working with and in the system after the first year } \\
\hline Pupils & Teachers \\
\hline $\begin{array}{l}\text { I have been into the system at school and my mother from home. } \\
\text { We have been talking about what I shall focus on at home. }\end{array}$ & $\begin{array}{c}\text { The students have in general understood the advantages of } \\
\text { working like this. They want to make progress to reach their } \\
\text { individual goals. }\end{array}$ \\
\hline Now I know where I am and what I need to focus on. & $\begin{array}{l}\text { Practically all students and parents have been positive working } \\
\text { with to the system. }\end{array}$ \\
\hline $\begin{array}{l}\text { This is better than before but I want even more information from } \\
\text { the teacher. }\end{array}$ & Now I get a better overview. \\
\hline $\begin{array}{l}\text { Now I get clear information about what and how to practise to } \\
\text { improve. }\end{array}$ & \\
\hline $\begin{array}{l}\text { When this is used all the way from year seven this will be } \\
\text { excellent! }\end{array}$ & \\
\hline
\end{tabular}

Corresponding Author:

Sveta Mayer ${ }^{1}$ Institute of Education, University of London.

Email: s.mayer@ioe.ac.uk 


\section{THE COLLABORATIVE BLENDED E-LEARNING ENVIRONMENT}

The case studies indicate successful personalisation of teaching and learning through application and engagement with assessment for learning to be dependent upon teachers and pupils collaboratively engaging in cycles of learning and formative assessment. Drawing upon these understandings an integrative Collaborative Blended e-Learning environment $(\mathrm{CBeL})$ is conceptualised within which adults and pupils are learners. In conceptualising $\mathrm{CBeL}$ it became evident the following features were integral component parts in establishing reciprocal cycles of personalised teaching and learning:

1. Collaborative participative learning through a process of goals orientated and problem-solving learning cycles experienced individually and in collaborative groups and involving both teachers and pupils.

2. Computer-aided on-line formative assessment tool for both teachers and pupils to initiate auditing of self and peer through formative assessment.

In this way $\mathrm{CBeL}$ as a collaborative learning environment facilitates learners in determining negotiated targets (objectives), actions to achieve these and assessing success in achieving these. Such a learning environment would be achieved by adults and pupils engaging in blended e-learning ( $\mathrm{ABeL}$ and $\mathrm{PBeL}$ ) programmes which embrace web based technologies to provide a significant element of e-learning and e-assessment but also carefully integrates this with face-to-face collaborative group facilitation to broaden, deepen, share and create new learning. The ABeL and PBeL programmes' platform would provide:

- Inclusion of , and reporting to, all stakeholders

- A simple curriculum design and e-assessment capture area

- An e-learning environment intuitively linked to the school level assessment

- Personalised choice of e-learning content

- Self and peer assessment criterion- referenced auditing tools

InfoMentor - My Learning Space (InfoMentor-MLS) has been designed to deliver ABeL and PBeL programmes and includes an online catalogue of think pieces, case studies and articles covering a wide spectrum of learning objectives related to national framework for teacher professional standards and national curriculum for pupils respectively. Each of which is punctuated with pertinent and well thought out online interventions in the form of critical questions to prompt engagement. InfoMentor - MLS will allow participants, both teachers and pupils to selfaudit and peer-audit against criteria referenced across a range of learning aspects which are both academic and personal. The process for engagement is blended e-learning with opportunities for participants to engage online but also engage face-to-face in collaborative groups in order to add the dimension of reflectivity and criticality.

For teachers $\mathrm{ABeL}$ is a professional development programme which engages them in collaborative work-based learning also develops their leadership capacity within school. Teachers work through the programme within a virtual learning environment. The curriculum content for teachers is focused upon leadership of learning and assessment and applying AfL strategies in their classroom to support pupils' learning. Within their virtual learning environment teachers access think pieces, case studies and articles, use critical thinking proformas and engage in online forums. They also formulate a question on assessment for leaning they wish to discuss in peer group seminar sessions. These facilitation sessions are designed to support teachers' collaboration and deliberation of new learning about applying AfL strategies to personalise teaching and learning in their classroom. Upon completion of the programme learning is codified into an individual learning profile. The process of blended e-learning for teachers is summarised in Fig 4.

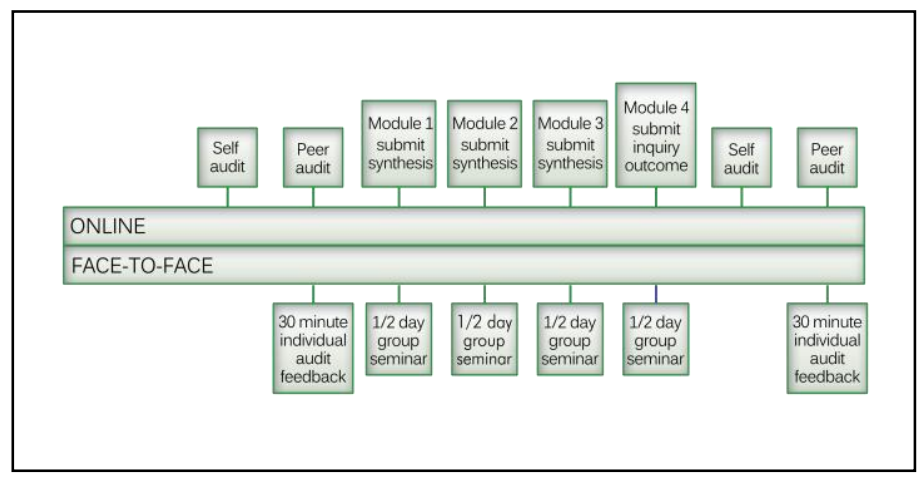

Corresponding Author:

Sveta Mayer ${ }^{1}$ Institute of Education, University of London.

Email: s.mayer@ioe.ac.uk 
Mayer, S, Cotgreave, G., Rosenkvist, M., Einarsdottir, V. and Osborne, P. (2011)

Proceedings of Annual International Conference on Education and E-Learning 2011 p136-145.

Global Science and Technology Forum: http://dl.globalstf.org/

Fig 4. The adult blended e-learning programme for teachers.

Pupils whose teachers are engaging in $\mathrm{ABeL}$ participate in PBeL. For these pupils, in practice traditional teaching and learning continues to take place within the confines of the classroom within which they are facilitated in engaging in cycles of learning and assessment. Following teacher assessment the learner is directed by their teacher to a personalised e-learning virtual classroom within which they can progress independently as appropriate to their individual learning needs. The link between the physical classroom and the virtual classroom is seamless. The virtual classroom allows the learner a significant degree of freedom and choice and extends the learning partnership to include their parents and carers. This process will allow participants to choose specific foci or to engage in the whole library of foci and then engage in critical reflection in order contextualise the issues.

Auditing of pupils' progress while they engage in PBeL will be as described for the InfoMentor System in this paper. For teachers, prior to starting ABeL, InfoMentor-MLS audits their current learning needs when they rate themselves against the learning criteria for the programme, which are designed to target teaching and learning and to achieving learning objectives, and requests peers to anonymously do the same. In this instance the learning objectives are construed around and related to teacher efficacy. There are Six inter-related domains which can be audited through InfoMentor-MLS: Strategy and Mission; Emotional/Political Acuity; Change Capability; System leadership; Enterprise and Efficiency. Each domain has a set of four self-evaluative statements. Responding to these statements support a reflective self-assessment rating through red, amber or green categories (Fig 5). InfoMentor-MLS reports the outcomes of these ratings. After engaging in the programme the process of rating is repeated to see if participants' and peers' perceptions have changed. InfoMentor-MLS reports on the postprogramme ratings and then reports changes. Facilitation is employed after each rating exercise to assist the participant to understand the rating reports. The process that teacher and pupil therefore engage in following blended e-learning programmes is shown in Fig 6.

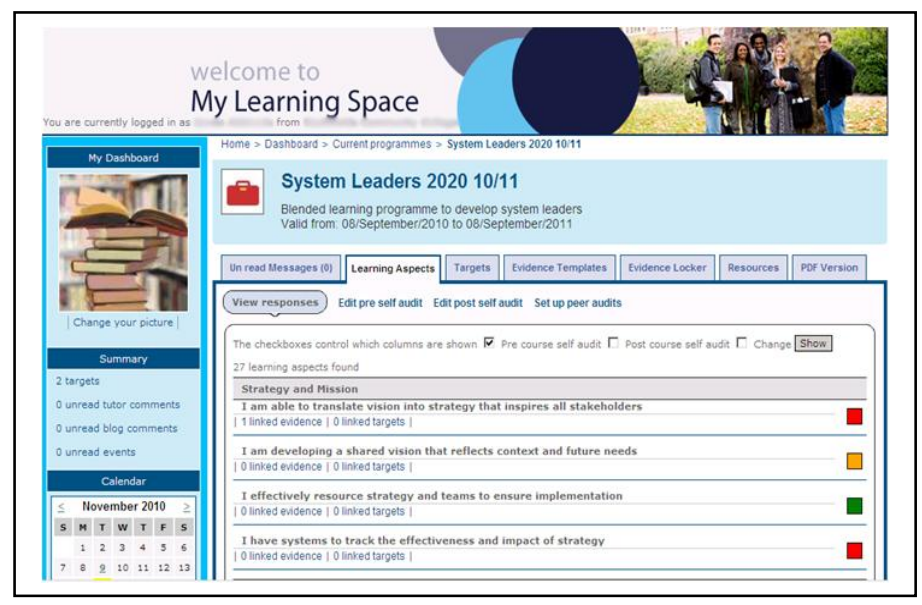

Fig 5 Screenshot of self audit for teachers engaging in the adult blended e-learning programme for teachers

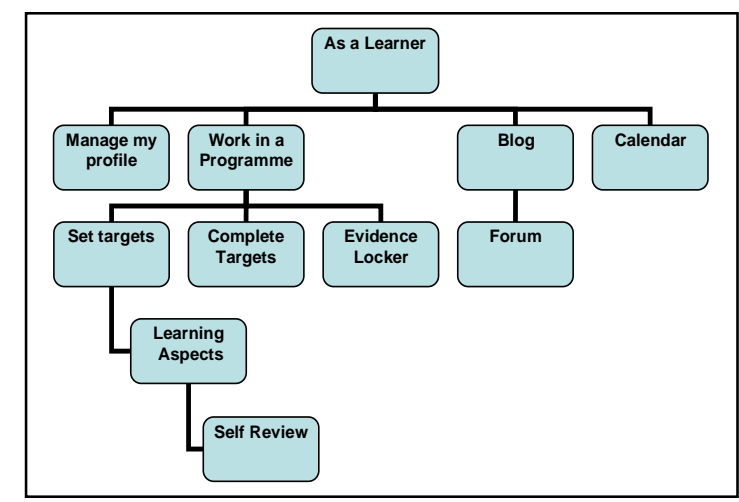

Fig 6. The integrated processes for learning and assessment teachers and pupils engage in through their respective blended e-learning programmes

Corresponding Author:

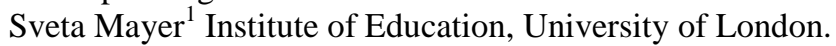

Email: s.mayer@ioe.ac.uk 
Mayer, S, Cotgreave, G., Rosenkvist, M., Einarsdottir, V. and Osborne, P. (2011)

Proceedings of Annual International Conference on Education and E-Learning 2011 p136-145.

Global Science and Technology Forum: http://dl.globalstf.org/

\section{SUMMARY}

The CBeL environment therefore integrates teacher (adult) and pupil blended e-learning (ABel and PBeL) such that in undertaking these programmes simultaneously there is a synergy of learning for teachers personalising teaching and learning for pupils in their classrooms and pupils achieving their learning objectives, goals and aspirations through personalised teaching and independent learning. $\mathrm{CBeL}$ as proposed in this paper for both teachers and pupils includes relevant:

- Participative face-to-face and on-line tools for collaborative learning and reification.

- Criterion-referenced learning objectives informed by national teacher standards for teachers and national curriculum for pupils.

- Meta-cognate self and peer formative assessment capture areas auditing progress in achieving learning objectives.

- Personalised choice of e-learning content though an on-line catalogue of learning materials and resources covering a wide spectrum of learning objectives.

In this way the $\mathrm{CBeL}$ environment enables the teacher to learn how best to 'personalise' pedagogy by assessing pupils' achievement/attainment and then reflecting upon the learning experience with pupils and parents. It also enables the pupil to become part of a learning dialogue with teachers and ensure learning is personalised to them and leading to increased outcomes. The $\mathrm{CBeL}$ environment is also being applied to a whole school context in which subject teachers, middle leaders and school leaders within education systems engage in synergistic collaborative cycles of learning and assessment to improve teaching and learning and raising outcomes for pupils.

\section{DISCUSSION}

We propose the $\mathrm{CBeL}$ environment conceptualised and presented here is an evidence based model representing a 'holistic' approach for adult and pupil collaborative learning. The design draws upon both objectivist and constructivist instructional design approaches [16]. The model engages collaborative learning between key stakeholders within the school setting. Pupils, parents, subject teachers and form teachers are involved in in-depth focus upon what is happening at the level of pupil. Inherent within the design of $\mathrm{CBeL}$ are iterative and reciprocal cycles of collaborative learning between teachers-and-pupils and also within both teacher and pupil peer groups (Fig 7). These collaborative learning cycles are initiated first by teachers [1].

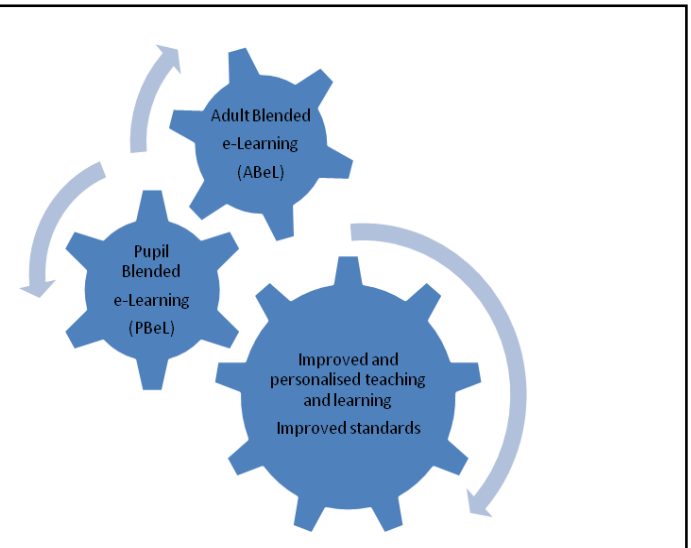

Fig. 7. The iterative and reciprocal cycles inherent within the collaborative blended e-learning environment.

For teachers these cycles are akin to the single, double and triple-loop feedback cycles of Torbert [17] within which teachers develop an ever increasing awareness of the context and situation within which they teach and also awareness of the individual learning needs of their pupils. This awareness begins and develops within their classroom with their own class pupils first and then, through their leadership, is disseminated within their department and then whole school. CBeL therefore provides a supportive collaborative learning environment within which teachers develop as distributed leaders. The role of strategic school leadership would be to invite their participation such that distributed leadership in practice was encouraged and recognised, adequate resources were provided and teachers given autonomy to initiate change in school practices. Doing this would lead to school improvement and reform [18], [19]. 
Mayer, S, Cotgreave, G., Rosenkvist, M., Einarsdottir, V. and Osborne, P. (2011)

Proceedings of Annual International Conference on Education and E-Learning 2011 p136-145.

Global Science and Technology Forum: http://dl.globalstf.org/

Pupils experiencing teaching and learning within such teachers' classrooms raises their own awareness of themselves as learners as they are directed towards goal-orientated solutions which they can achieve through their own actions. This develops their cognitive and affective skills on an on-going basis each day [20]. For as teachers support pupils' learning through differentiated pedagogy targeting pupils' development within their Zone of Proximal Development [21], [22] the pupils experience learning at their Zone of Current Development such that they progressively move towards achieving their learning objectives or goals [20]. Within the context of CBeL this is supported by engaging pupils in meta - cognitive self-appraisal and peer-appraisal with goal setting establishing the pupils' learning intentions and assessment verifying their progression. This is motivating them to learn.

Finally, the CBeL model enables teachers to personalise teaching and learning by inviting pupils' participation. If this is considered within Hart's framework for participation, the CBeL model as conceptualised here falls at rung level 6 whereby participation is adult-initiated and the decision-making about pupils' learning experiences is negotiated by adults (teachers, parents) with children [1]. We considered this would be relevant and applicable to pupils' engaging in academic learning but the experience of this may be perceived differently if applied by teachers or parents when discussing pupils' personal development. Adult-child relationships and dialogue [23], [3] within the educational context as advocated here is an important aspect to the CBeL model to ensure a safe, honest and nurturing learning environment for both teachers-as-learners and pupils-as- learners.

\section{ACKNOWLEDGMENT}

The authors thank participants EW, RD, AS, her parent and her teachers for their cooperation and for allowing the authors to include their data and information pertinent to the preparation of this paper. References

[1] Hart, R. (1992) Children's Participation: from tokenism to citizenship Innocenti: UNICEF p8

[2] Beetham, H. and Sharpe, R. (2007) Rethinking Pedagogy for a Digital Age. London: Routledge

[3] Fielding, M. (2009) Interrogating student voice: pre-occupations, purposes and possibilities In, H. Daniels, H. Lauderand and J. Porter (eds) Educational Theories, Cultures and Learning: A Critical Perspective, p101-116 London: Routledge

[4] Yin Yin, R. K. (2003) Applications of Case Study Research, $2^{\text {nd }}$ edn. CA: Sage

[5] Lave, J. and Wenger, E. (1991) Situated Learning: Legitimate Peripheral Participation Cambridge: Cambridge University Press

[6] Wenger, E., McDermott, R., and Snyder, W. (2002) Cultivating Communities of Practice. Boston: Harvard Business School

[7] Creswell, J.W. (1998) Qualitative Inquiry and Research Design: Choosing Among Five Traditions. CA:Sage

[8] BERA (2004) Revised Ethical Guidelines for Educational Research (2004) http://www.bera.ac.uk/files/2008/09/ethica1.pdf Accessed September 2011

[9] Mayer, S. (2009) Engagement in school-based collaborative enquiry. Professional Development Today $\underline{12.3}$ : 53-56

[10] Lewin, K. (1946) Action Research and Minority Problems Journal of Social Issues 2 34-36

[11] Kemmis, S. and McTaggart, R. (1992) The Action Research Planner (third edition) Geelong, Vic.: Deakin University Press

[12] Bray, J.N., Lee, J., Smith, L., and Yorks, L. (2000) Collaborative Inquiry in Practice London: SAGE

[13] Mayer, S. (2010) Designing, building and engaging inquiry-based professional learning communities in schools: A case study of two pilot schools. Conference Paper presented at International Congress for School Effectiveness and Improvement, 5-8 ${ }^{\text {th }}$ January 2010, Kuala Lumpur, Malaysia

[14] Black, P., Harrison, C., Lee, C., Marshall, B., and Wiliam, D. (2003) Assessment for Learning: Putting it into Practice Maidenhead: OUP

[15] Scriven, M. (1996) Types of evaluation and types of evaluator Evaluation Practice 17(2) 151-161 Torbert, B. (2004) Action Inquiry CA: Berrett-Koehler Publishers, Inc

[16] Young, M. (1993) Instructional design for situated learning Educational Technology Research and Development 41 (1) 43-58

[17] Torbert, B (2004) Action Inquiry: The Secret of Timely and Transforming Leadership San Francisco, CA: Berrett-Koehler

[18] Harris, A., Leithwood, K., Day, C., Sammons, P., \& Hopkins, D. (2007). Distributed Leadership and Organiszational Change: Reviewing the Evidence. Journal of Educational Change, 8, 337-347.

[19] Mayrowetz, D., Murphy, J., Seashore Louis, K. and Smylie, M. (2009) Conceptualising distributed leadership as a school reform, In, K. Leithwood, B. Mascall and T. Strauss (eds) Distributed Leadership According to the Evidence p167-195 London: Routledge

[20] Granott, N. (2002) How microdevelopment creates macrodevelopment: Reiterated sequences, backward transitions, and the zone of current development. In, N. Granott and J. Parzale (eds), Microdevelopment: Transition Processes in Development and Learning (pp. 213-242). Cambridge: Cambridge University Press

[21] Vygotsky, L. (1978) Mind in Society: The development of higher psychological processes Cambridge, MA: Harvard University Press

[22] Sousa, D. and Tomlinson, C.A. (2011) Differentiation and The Brain Bloomington, IN: Solution Tree Press

[23] Manion, G. (2007) Going Spacial, Going Rational: Why “listening to children" and Children's participation needs reframing Discourse 28 (3) $405-420$ 